\title{
Perception of Adolescent Patients on Cooperation During Orthodontic Treatment: A Qualitative Study
}

\author{
Percepción de los Pacientes Adolescentes sobre Cooperación \\ Durante el Tratamiento Ortodóncico: Un Estudio Cualitativo
}

\begin{abstract}
Laura Maria Castellanos Giraldo*; Ana Cecilia Pérez Rendón*; Alejandro Gallón Londoño*** \& Juan Manuel Cárdenas Vásquez ${ }^{* \star *}$
\end{abstract}

CASTELLANOS, G. L. M; PÉREZ, R. A. C.; GALLÓN, L. A. \& CÁRDENAS, V. J. M. Perception of adolescent patients on cooperation during orthodontic treatment: a qualitative study. Int. J. Odontostomat., 8(2):225-228, 2014.

ABSTRACT: The objective of the present study was to identify the fundamental factors associated with patient cooperation during orthodontic treatment. A qualitative study was carried out, following a hermeneutical approach, using focus groups as the data collection instrument. Sample selection consisted of adolescent patients undergoing orthodontic treatment at CES University Dental Clinics in Medellin, Colombia. Each focus group was directed by trained psychologists. Transcriptions were carried out and afterwards analyzed. Two focus groups, each consistent of 17 patients ranging between 11 and 18 years of age, who were in active orthodontic treatment were evaluated. Five significant factors associated with patient cooperation were identified which included, knowledge, empathy, esthetics, friendly environment, and inclusion in treatment.

KEY WORDS: Cooperation, orthodontic treatment, adolescence, perception.

\section{INTRODUCTION}

Orthodontic treatment is designed to correct and improve those conditions that affect anatomical and functional relations, in order to obtain facial harmony and esthetics. Adolescence is the most appropriate age to begin orthodontic treatment given the possibility of significantly modifying craniofacial growth and esthetics. However, negligence regarding the use of appliances and lack of compliance with instructions given by the orthodontist are both common problems among these patients (Albino et al., 1991; Ruiz, 1995).

Although one of the most significant factors in treatment success is patient compliance, studies suggest that approximately $25 \%$ to $50 \%$ of adolescents in the United States do not follow instructions given by professionals (Bos, 2005a, 2005b), which can lead to an early conclusion or suspension of treatment (Moss et al., 1981).
Different studies have evaluated factors which could be associated with lack of cooperation and treatment success in orthodontics which can be divided into extrinsic and intrinsic factors.

Among the extrinsic factors, type of practice, communication between patient and parents and communication between patients and their orthodontist seem to be associated with cooperation (Patel, 1992; Mehra et al., 1998), while others such as type of appliance and socio-economic status do not seem to have impact upon treatment success and compliance (Albino et al.; Patel; Mandall et al., 2008).

Other studies have evaluated intrinsic factors such as patient personality, age, sex; self-esteem and need for treatment revealing controversial results that do not allow definite conclusions or correlation between them and cooperation (Albino et al.; Merah et al.; Sergl et al., 1992).

Clinical Instructor, Department of Orthodontics, School of Dentistry, CES University, Medellín, Colombia.

** Private Practice limited to Orthodontics, Medellín, Colombia.

*** Associate Professor, School of Psychology, CES University, Medellín, Colombia.

${ }^{* * * *}$ Assistant Professor Pediatric Dentistry, School of Dentistry, CES University, Medellín, Colombia.

Funding: This work was supported by CES University [200807DI08]. 
Qualitative evaluation of these studies shows important limitations given that they are focused on evaluating the impact of individual variables in an objective manner through psychometric scales and not at assessing the comprehensive nature of the problem in a subjective form. In this regard, the use of qualitative methods that can incorporate and analyze different factors simultaneously could offer a better understanding of the problem.

Qualitive methodology through the use of focus groups has been extensively documented and dates back to 1930 due to the controversy created regarding the accuracy of traditional data collection methods in social research (Lewis, 2000).

Focus groups have become the main tool in qualitative research and have proven to be a reliable method for generating new information by creating ideas and hypotheses as well as serving as a platform for the initiation of quantitative studies (Sergl et al., 2000). Currently, focus groups are not only used for social research and marketing but also in other areas such as health in order to evaluate patient perceptions of educational campaigns and more recently in orthodontics (Kitzinger, 1995).

Given the above, the purpose of this study was to identify the factors associated with patient compliance during orthodontic treatment with the use of focus group methodology.

\section{MATERIAL AND METHOD}

A qualitative study was carried out, following a hermeneutical approach, using focus groups as the data collection instrument. This method consists of group meeting sessions between 6 and 12 individuals guided by a trained moderator in which there is an open and structured discussion about a specific topic. The purpose is to establish conclusions based on interactions and agreements subscribed by participants regarding their knowledge, attitudes, feelings, beliefs and experiences (Lewis).

In order to select the sample, 70 patients between 11 and 18 years old who were undergoing orthodontic treatment at CES University Dental Clinics in Medellin, Colombia were invited to participate in the study. A total of 17 patients accepted and were divided in two groups, one of 8 individuals ( 7 males, 1 female) and another of 9 individuals (6 males, 3 females). Written informed consent was obtained from all patients, parents or guardians, and the study protocol, was approved by the ethics committee of CES University.

Groups were directed by psychologists trained in the management of this methodology, who evaluated four categories based on the most common factors reported in previous studies. These included definition of cooperation, professional-patient relationship, methods for treatment motivation and external factors such as previous experiences, dental office environment, family support and costs. An outline was created, which was flexible depending on the participation of each subject.

Two sessions, of approximately two hours for each group, were held and recorded on audio tapes. Recordings were afterwards transcribed by an independent individual and a qualitative analysis of the transcriptions was made by the authors in order to generate the results of the study. Neither the treating orthodontic resident, instructors or investigators were present during the sessions. Informed consents were obtained from parents prior to the initiation of each meeting.

\section{RESULTS AND DISCUSSION}

After assessment of transcripts, five significant factors were identified associated with patient cooperation which included knowledge, empathy, inclusion in treatment, esthetics and friendly environment.

With regards to knowledge, it was evident from the interpretations that it is one of the most important factors which patients look for when being treated. This was perceived as the scientific background, clinical dexterity and the ability of the orthodontist to demonstrate self-confidence which creates a sense of trust. In addition patients also expressed fear that their orthodontist might make mistakes, and in the case of this study in which treatment was rendered by residents, many expressed that they preferred the professor to be present and support them. Participants also stated that receiving an explanation of the procedures to be performed during each appointment was essential to them (Table I).

Another factor discussed by patients was the relevance of being treated not only as a patient but also as a friend by the orthodontist which can be described as empathy with the professional. They expressed that 
this motivated them to cooperate more with treatment, follow instructions and comply with appointments. Regarding this matter, patients spoke of the importance of the first impression and how the attitude, the way in which they were greeted and treated during the initial appointment, allowed them to establish an impression which encouraged or discouraged them to initiate the treatment. Equally relevant is the perception of responsibility, and availability of the professional to answer their doubts or questions as well as the time dedicated to them during consultation (Table I).

Inclusion in the treatment process also seems to influence cooperation. Patients pointed out that to decrease anxiety generated before arriving to the dental office, they expected to receive an explanation of the specific procedures to be carried out during the following appointment. They also expressed that they would like to know if they were going to feel pain or discomfort in order to prepare themselves and to know that these sensations were normal and temporary. It was also found that patients need to observe improvements achieved at every appointment to encourage them to better adjust to changes generated by orthodontic treatment. Participants were also aware that a good attitude was essential by both the orthodontist and the patient for treatment success.

Great importance was also given by patients to esthetics which was in many instances their chief complaint. They emphasized that esthetics were essential for their future and believed it would help them to be professionally successful and more accepted by society. They also manifested that as they observed improvement and perceived that the professional cared about their esthetics, they were more compliant and confident (Table I).

Finally, patients seem to give relevance to the environment of the dental office. It was important for them to feel that the office setting was clean and organized which they associated with the execution of a good treatment. Attitude of the office staff and punctuality were also highly valued as well as an appropriate explanation in cases of delay (Table I).

Table I. Patient comments transcribed during focus group meetings.

\begin{tabular}{|c|c|}
\hline Factors & Comments of the patients \\
\hline Knowledge & $\begin{array}{l}\text { "Since they are students, sometimes you are afraid they make mistakes" } \\
\text { "Every appoi ntment I come to, he or she knows what to do, but he or she also calls the } \\
\text { professor to find out what else can be done. That feels good" } \\
\text { "The most important issue is confidence, since one can not open his mouth to a person } \\
\text { one does not trust" } \\
\text { "He or she is distracted, sometimes it is like he or she forgets things" }\end{array}$ \\
\hline Empathy & $\begin{array}{l}\text { "I say, if you do not get along with your doctor, you will feel bored and will stop using the } \\
\text { appliances that depend on you, you do not take care of yourself" } \\
\text { "You meet a person, see how they are and you get an impression. My first impression was not } \\
\text { good; therefore I was afraid of being around her" }\end{array}$ \\
\hline $\begin{array}{l}\text { Inclusion in } \\
\text { treatment }\end{array}$ & $\begin{array}{l}\text { "Another thing I like about my doctor is that she explains everything so I can understand" } \\
\text { "I did not know that by the time they took of your braces you had to pay more money for } \\
\text { the retainers; it was a surprise for me and my mother" } \\
\text { "I am worried about the procedures to be carried out on me during that day, how painful } \\
\text { they will be, because sometimes the doctor places appliances that are too tight and this } \\
\text { may cause some anguish" } \\
\text { "At first, as it is so painful, one feels like taking the braces off, but after a while you get } \\
\text { used to them and you know you have to make it to the end of the treatment" }\end{array}$ \\
\hline Esthetics & $\begin{array}{l}\text { "One is undergoing treatment to change the physical aspect, teeth above all, because } \\
\text { when one is about to begin to w ork, people will see how one looks like, beginning with } \\
\text { your teeth." } \\
\text { "When they put these braces on, I felt horrible, I did not like the way I looked, I did not } \\
\text { even talk to my friends, I felt so bad" } \\
\text { "One can see the changes every day and therefore one knows that it is important to go } \\
\text { to the next appointment in order to see more changes" }\end{array}$ \\
\hline $\begin{array}{l}\text { Friendly } \\
\text { environment }\end{array}$ & $\begin{array}{l}\text { "The environment influences very much. For example, if one sits in a filthy chair it is } \\
\text { impossible that a go od treatment be performed, specially considering that being related } \\
\text { to the oral cavity it requires a lot of cleanliness" }\end{array}$ \\
\hline
\end{tabular}




\section{CONCLUSIONS}

Knowledge, empathy, feeling part of the treatment, esthetics, and a friendly environment are factors identified by patients as indispensable in order to cooperate during orthodontic treatment.

Health was not an exclusive factor to motivate patients to cooperate during orthodontic treatment.

Training and emphasis during postgraduate orthodontic training on patient cooperation topics is recommended given its importance in the final outcome of treatment.
It is important to consider that results of this study are the product of an analysis of patients treated in a University setting, and it would therefore be recommendable that future studies evaluate cooperation in private practice settings where differences could be observed.

ACKNOWLEDGMENTS. The authors wish to express their acknowledgments to Doctor Diego Rey Mora for his assistance in the preparation of this paper, and in a very special manner to the late Doctor Tiziano Baccetti for his guidance in the formulation of the study and reviewing the manuscript.

CASTElLANOS, G. L. M; PÉREZ, R. A. C.; GALLÓN, L. A. \& CÁRDENAS, V. J. M. Percepción de los pacientes adolescentes sobre cooperación durante el tratamiento ortodóncico: un estudio cualitativo. Int. J. Odontostomat., 8(2):225-228, 2014.

RESUMEN: El objetivo del presente estudio fue identificar los factores fundamentales relacionados con la cooperación de los pacientes adolescentes durante el tratamiento de ortodoncia. Se realizó un estudio cualitativo, utilizando grupos focales como el instrumento de recolección de datos. La selección de la muestra consistió en pacientes adolescentes que reciben tratamiento de ortodoncia en la clínica de Ortodoncia de la Universidad, CES, Medellín, Colombia. Cada grupo focal fue dirigido por psicólogos entrenados y fue grabado para luego realizar la transcripción de cada uno. Fueron evaluadosos dos grupos focales, cada uno de 17 pacientes entre los 11 y 18 años de edad, que estaban en tratamiento activo de ortodoncia. Se identificaron cinco factores importantes relacionados con la cooperación del paciente, estos fueron: el conocimiento que el profesional demuestra tener frente a su paciente, la empatía entre el ortodoncista y el paciente, la estética, el ambiente clínico favorable y la inclusión de los pacientes en el tratamiento.

PALABRAS CLAVE: cooperación, tratamiento de ortodoncia, adolescencia, percepción.

\section{REFERENCES}

Albino, J. E.; Lawrence, S. D.; Lopes, C. E.; Nash, L. B. \& Tedesco, L. A. Cooperation of adolescents in orthodontic treatment. J. Behav. Med., 14(1):53-70, 1991.

Bos, A.; Hoogstraten, J. \& Prahl-Andersen, B. Attitudes towards orthodontic treatment: a comparison of treated and untreated subjects. Eur. J. Orthod., 27(2):148-54, 2005.

Bos, A.; Hoogstraten, J. \& Prahl-Andersen, B. The theory of reasoned action and patient compliance during orthodontic treatment. Community Dent. Oral Epidemiol., 33(6):419-42, 2005.

Kitzinger, J. Qualitative research. Introducing focus groups. BMJ, 311(7000):299-302, 1995.

Lewis, M. Focus Group Interviews in Qualitative Research: A Review of the Literature. Action Research E-Reports. 2000. Disponible en: http://www.fhs.usyd.edu.au/arow/arer/002.htm

Mandall, N. A.; Matthew, S.; Fox, D.; Wright, J.; Conboy, F. M. \& O'Brien, K. D. Prediction of compliance and completion of orthodontic treatment: are quality of life measures important? Eur. J. Orthod., 30(1):40-5, 2008.

Mehra, T.; Nanda, R. S. \& Sinha, P. K. Orthodontists' assessment and management of patient compliance. Angle Orthod., 68(2):115-22, 1998
Moss, J. P.; Williams, D. W. \& Cohen, A. M. Experience in providing orthodontic treatment in England. Eur. J. Orthod., 3(2):135-9, 1981.

Patel, V. Non-completion of active orthodontic treatment. Br. J. Orthod., 19(1):47-54, 1992.

Ruiz, M. T. Conocimientos, actitudes y comportamiento sexual de los adolescentes. Santa Fé de Bogotá, Profamilia, 1995.

Sergl, H. G.; Klages, U. \& Pempera, J. On the prediction of dentistevaluated patient compliance in orthodontics. Eur. J. Orthod., 14(6):463-8, 1992.

Sergl, H. G.; Klages, U. \& Zentner, A. Functional and social discomfort during orthodontic treatment--effects on compliance and prediction of patients' adaptation by personality variables. Eur. J. Orthod., 22(3):307-15, 2000.

Correspondence to:

Laura Castellanos Giraldo

Clinical Instructor

Department of Orthodontics

School of Dentistry

CES University

Medellín

COLOMBIA

Received: 24-06-2013

Accepted: 18-02-2014

Email: lauracgiraldo@hotmail.com 